\title{
Identification and Characterization of a Peptide with Affinity to Head and Neck Cancer
}

Eva-Maria Nothelfer ${ }^{1,2}$, Sabine Zitzmann-Kolbe ${ }^{3}$, Regine Garcia-Boy ${ }^{1}$, Susanne Krämer ${ }^{1}$, Christel Herold-Mende ${ }^{4}$, Annette Altmann ${ }^{1,2}$, Michael Eisenhut ${ }^{5}$, Walter Mier ${ }^{1}$, and Uwe Haberkorn ${ }^{1,2}$

${ }^{1}$ Department of Nuclear Medicine, University of Heidelberg, Heidelberg, Germany; ${ }^{2}$ Clinical Cooperation Unit Nuclear Medicine, German Cancer Research Centre (DKFZ), Heidelberg, Germany; ${ }^{3}$ Bayer Schering Pharma AG, Berlin, Germany; ${ }^{4}$ Department of Neurosurgery, Division of Neurosurgical Research, University of Heidelberg, Heidelberg, Germany; and ${ }^{5}$ Department of Radiopharmaceutical Chemistry, German Cancer Research Centre (DKFZ), Heidelberg, Germany

Combination therapy has improved the quality of life for patients with squamous cell carcinomas of the head and neck (HNSCCs) but has not decisively changed prognosis. Targeted therapies, which enhance accumulation of the drug in the tumor, may be realized using tumor-specific binding peptides. This paper identifies and characterizes an HNSCC affine peptide. Methods: From a phage library comprising $10^{9}$ different displayed peptides, 1 peptide was enriched after 5 in vitro selection rounds on HNO223 tumor cells. Subsequently, the gained peptide sequence $\mathrm{H}_{2} \mathrm{~N}-\mathrm{SPRGDLAVLGHKY}-\mathrm{CONH}_{2}(\mathrm{HBP}-1)$ was synthesized as an amide and labeled with ${ }^{125} \mathrm{I}$. In vitro studies for binding kinetics and competition were performed with 5 different HNSCC cell lines. Furthermore, the stability of the peptide was evaluated in human serum. The in vivo biodistribution of ${ }^{131}$ Ilabeled peptide was determined in HNSCC tumor-bearing nude mice. The results were further validated in human HNSCC tumor tissue sections using fluorescence-labeled HBP-1. Competition experiments were performed to determine the binding sequence and validate the target. Results: The HBP-1 motif was enriched in $62 \%$ of all phages sequenced. Labeled ${ }^{125} \mathrm{I}-\mathrm{HBP}-1$ showed binding to 5 different HNSCC cell lines and a maximum binding to HNO97 cells, with $11 \%$ of the applied dose per $10^{6}$ cells and an inhibitory concentration of $50 \%$ of $38.9 \mathrm{nM}$. Stability experiments in human serum showed a half-life of $55 \mathrm{~min}$. In 2 different HNSCC tumor xenografts, ${ }^{131} \mathrm{I}-\mathrm{HBP}-1$ accumulated rapidly, with stable uptake until 45 min after intravenous application. Peptide immunohistochemistry of HNSCC tissue sections exhibited tumor staining by HBP-1, whereas normal tissue remained negative. Sequence mutation and competition experiments revealed that the intrinsic RGD motif in combination with the intrinsic LXXL motif is responsible for the binding ability of HBP1. The RGDLXXL sequence within this peptide is known and indicates that binding occurs via the $\alpha_{v} \beta_{6}$ rather than the $\alpha_{v} \beta_{3}$ integrin. Conclusion: Within the sequence of HBP-1 is a RGDLXXL motif, and most likely it is targeting the $\alpha_{\mathrm{v}} \beta_{6}$ receptor of the integrin family of cell adhesion receptors. HBP-1 represents a promising lead structure for the development of targeted therapies or diagnostic procedures in patients with HNSCC.

Received Sep. 15, 2008; revision accepted Nov. 25, 2008.

For correspondence or reprints contact: Eva-Maria Nothelfer, Department of Nuclear Medicine, University of Heidelberg, Im Neuenheimer Feld 400,

D-69120, Heidelberg, Germany.

E-mail: E.Nothelfer@dkfz.de

COPYRIGHT $\odot 2009$ by the Society of Nuclear Medicine, Inc.
Key Words: tumor targeting; peptides; RGD; phage display; integrin $\alpha_{v} \beta_{6}$; head and neck cancer

J Nucl Med 2009; 50:426-434

DOI: 10.2967/jnumed.108.058123

M ore than $5 \%$ of all malignant tumors worldwide are head and neck cancer, with more than 100,000 cases diagnosed in Europe each year. In the Western world, squamous cell carcinoma of the head and neck (HNSCC) accounts for more than $90 \%$ of all head and neck cancers (1). Most cases are diagnosed in patients who are between 50 and $70 \mathrm{y}$ old, with a 5 times higher rate for men than for women. The 5-y survival rate of less than $30 \%$ is due to a high lymphogenic metastatic tendency, a high recurrence rate, and an increased occurrence of secondary tumors. Treatment strategies for advanced HNSCC have evolved from less effective monotherapy to an integrated, more effective multidisciplinary approach. A new field under investigation in advanced tumors is targeted therapy. Several potential targets have been discovered in a variety of tumors (2). Tumorspecific receptors can be targeted by antibodies, peptides, and tyrosine kinase inhibitors (cetuximab and gefitinib (3), and cilengitide (4)). In the case of HNSCC, the first promising results with the targeted approach were reported for the angiogenic peptide RGD cilengitide. It specifically targets the $\alpha_{v} \beta_{3}$ integrin receptor, which is present in the highly vascularized head and neck tumors (4).

The potential of screening phage display libraries lies in providing antigen/receptor binding molecules that are selected from an enormous array of potential ligands. Thus, the identification of novel targets is enabled, and novel molecules can be provided that specifically bind to a given or any unknown target. Phage display has been applied for a variety of purposes, including the mapping of epitopes, the identification of new receptors, the isolation of specific antigens, the production of novel enzyme inhibitors (5), and the identification of high-affinity antibodies and peptides (6). For tumor targeting, peptides have been shown to be 
useful either as carriers of chemotherapeutic drugs and toxic molecules or as radioactive tracers for noninvasive diagnosis and therapy. Thus, radiolabeled peptides have been used in the past for the noninvasive assessment of receptor density or angiogenesis in tumors.

In this study, we characterize $\mathrm{H}_{2} \mathrm{~N}$-SPRGDLAVLGHKY$\mathrm{CONH}_{2}$ (HBP-1), a new linear peptide, which was selected via phage display screening against an HNSCC cell line. Affinity of HBP-1 to different HNSCC cell lines and its kinetics and internalization were determined in cell-binding assays. Binding to the original tumor was confirmed by peptide staining of tumor slices and uptake into HNSCC tumor-bearing mice. HBP-1 contains the well-known RGD motif in combination with an LXXL motif. The presence of those 2 motifs led to the analysis of their contribution to HBP-1 uptake. In this regard, a preference of HBP-1 to $\alpha_{\mathrm{v}} \beta_{6}$ over $\alpha_{\mathrm{v}} \beta_{3}$ was found. The data are evidence for a possible use of HBP-1 as a new lead structure for HNSCC targeting.

\section{MATERIALS AND METHODS}

\section{Cell Lines}

The HNSCC cell lines HNO97, HNO210, HNO223, HNO237, and $\mathrm{HNO} 222$ (7) and the human breast cancer cell line MCF-7 (American Type Culture Collection) were cultivated in Dulbecco's modified Eagle medium with GlutaMAX and high-glucosecontaining 10\% fetal calf serum (Gibco, Invitrogen Life Technologies) and $25 \mathrm{mM} \mathrm{N}$-2-hydroxyethylpiperazine- $\mathrm{N}$-2-ethanesulfonic acid. The spontaneously immortalized epithelial human mammary breast cell line MCF-10A (American Type Culture Collection) was cultivated in MEGM BulletKit Clonetics Media System (Cambrex Bio Science Walkersville). The human gingival mucosa keratinocyte cell line HPV-16GM immortalized with gene E6 and E7 of HPV16 was cultivated with serum-free keratinocyte growth medium completed with supplement mix c-39016 (PromoCell $\mathrm{GmbH}$ ). Human umbilical vein endothelial cells were isolated as previously described $(8)$ and cultivated on $1 \%$ gelatincoated cell culture flasks using endothelial cell growth medium 2 with supplement mix (PromoCell $\mathrm{GmbH}$ ). All cells were incubated at $37^{\circ} \mathrm{C}$ and at $5 \% \mathrm{CO}_{2}$.

\section{Selection of Tumor Cell-Binding Peptides}

For biopanning, a linear 12-amino-acid peptide library (Ph.D.12; New England Biolabs) was used. Each selection round was conducted as follows: $5 \times 10^{10}$ plaque-forming units were added to HPV-16GM cells for negative selection. After $1 \mathrm{~h}$, the medium was collected and centrifuged for $5 \mathrm{~min}$ at $1,500 \mathrm{~g}$, and the supernatant was transferred to $\mathrm{HNO} 223$ cells grown to $90 \%$ confluency. After $1 \mathrm{~h}$, the cells were washed 4 times with 10 $\mathrm{mL}$ of Hanks' balanced salt solution(+) (Gibco, Invitrogen Life Technologies) plus $1 \%$ bovine serum albumin (BSA) and 4 times with $10 \mathrm{~mL}$ of Hanks' balanced salt solution(-) plus 1\% BSA. The cells were then incubated with $5 \mathrm{~mL}$ of phosphate-buffered saline plus $1 \mathrm{mM}$ ethylenediamine tetraacetic acid for $10 \mathrm{~min}$ and subsequently with $5 \mathrm{~mL}$ of $0.05 \%$ trypsin-ethylenediamine tetraacetic acid (Gibco, Invitrogen Life Technologies) until the cells became detached. The cells were centrifuged for $5 \mathrm{~min}$ at $1,500 \mathrm{~g}$. The cell pellet was washed 3 times with $1 \mathrm{~mL}$ of Hanks' balanced salt solution(-) plus $1 \%$ BSA and lysed with $1 \%$ Triton X-100 solution. Lysate $(10 \mu \mathrm{L})$ was used for titration of the phages on IPTG/X-Gal (Fermentas) lysogeny broth agar plates. The remaining lysate was amplified in $50 \mathrm{~mL}$ of ER2537 bacteria according to the manufacturer's protocol. For the following 5 selection rounds, approximately $10^{11}$ plaque-forming units were used. Thereafter, phage single-stranded DNA isolation was done from the resulting clones (QIAprep Spin M13 Kit; Qiagen). The peptide was identified by DNA sequencing and subsequently analyzed with HUSAR map (HUSAR Biocomputing Service at the German Cancer Research Center).

\section{Peptides}

The peptide HBP-1 and its modifications, HBP-AGA $\left(\mathrm{H}_{2} \mathrm{~N}-\mathrm{SPA}-\right.$ GALAVLGHLY-CONH ${ }_{2}$, HBP-AXXA ( $\mathrm{H}_{2} \mathrm{~N}$-SPRGDAAVAGHKYCONH2), A20FMDV2 ( $\mathrm{H}_{2} \mathrm{~N}-\mathrm{NAVPNLRGDLQVLAQKVARTY),}$ and TPH2009.1 $\left(\mathrm{H}_{2} \mathrm{~N}\right.$-RGDLATLRQLAQEDGVVGVRY-CONH $\left.{ }_{2}\right)$, were obtained by solid-phase peptide synthesis using Fmoc chemistry (9). The peptides were purified by high-pressure liquid chromatography (HPLC) on a Chromolith Semi Prep Column $\mathrm{RPe} 18,10 \times 100 \mathrm{~mm}$ (Merck), with a linear gradient of water and acetonitrile containing $0.1 \%$ trifluoroacetic acid and subsequent lyophilization. The radiolabeling was achieved by iodination on the $\mathrm{C}$ terminus-attached tyrosine residue using the chloramine- $\mathrm{T}$ method (10). The labeled peptide was purified and analyzed on a Chromolith Performance RP-18e $100 \times 4.6 \mathrm{~mm}$ column (Merck) using a linear gradient of water and acetonitrile containing $0.1 \%$ trifluoroacetic acid as eluents. The specific activities obtained were $90 \mathrm{GBq} / \mu \mathrm{mol}$ for the ${ }^{125}$ I-labeled peptide and $110 \mathrm{GBq} /$ $\mu \mathrm{mol}$ for the ${ }^{131}$ I-labeled peptide. Additionally, HBP-1 was coupled to fluorescein isothiocyanate (FITC) isomer I (Fluka) via an extra lysine at the $\mathrm{C}$ terminus. The cRGD cyclo-(RGDdFV) peptide (Bachem AG) was used as competitor for in vitro binding experiments.

\section{In Vitro Binding Experiments}

Cells $\left(6 \times 10^{5}\right)$ were seeded into 6-well plates and cultivated for $24 \mathrm{~h}$. The medium was replaced by $1 \mathrm{~mL}$ of fresh medium (without fetal calf serum) containing $1 \%$ BSA. ${ }^{125}$ I-labeled peptide was added to the cell culture and incubated for the appropriate times, varying from $10 \mathrm{~min}$ to $6 \mathrm{~h}$. For competition experiments, $100 \mu \mathrm{L}$ of unlabeled peptide $\left(10^{-4} \mathrm{M}-10^{-12} \mathrm{M}\right)$ were added simultaneously with the radioactive peptide $\left(10^{6} \mathrm{cpm}\right.$ per well) and incubated for $30 \mathrm{~min}$. After incubation, the cells were washed 3 times with $1 \mathrm{~mL}$ of phosphate-buffered saline $(\mathrm{pH}$ 7.4) and subsequently lysed with $0.3 \mathrm{M} \mathrm{NaOH}(0.5 \mathrm{~mL})$. Radioactivity was determined with a $\gamma$-counter and calculated as percentage of the applied dose per $10^{6}$ cells. Each experiment was performed 3 times, and 3 repetitions per independent experiment were acquired.

\section{Internalization Experiments}

Internalization experiments were performed in vitro after seeding of $6 \times 10^{5}$ HNO97 cells $\left(6 \times 10^{5}\right)$ in 6-well plates. After $24 \mathrm{~h}$ of incubation, the medium was replaced by $1 \mathrm{~mL}$ of medium containing $1 \%$ BSA without fetal calf serum. ${ }^{125}$ I-labeled peptide was added to the cells and incubated for 10,60 , and $120 \mathrm{~min}$ at $4^{\circ} \mathrm{C}$ and at $37^{\circ} \mathrm{C}$. The same conditions were applied using $100 \mu \mathrm{L}$ of unlabeled peptide $\left(10^{-4} \mathrm{M}\right)$ together with the labeled peptide to ensure specific binding. After incubation, the cells were washed 
3 times with $1 \times$ phosphate-buffered saline $(\mathrm{pH} 7.4)$. For the $4^{\circ} \mathrm{C}$ incubated cells, all washing steps were performed with $4^{\circ} \mathrm{C}$ cold buffers. Two washing steps with glycine buffers $(50 \mathrm{mM}$ glycine, $100 \mathrm{mM} \mathrm{NaCl}, \mathrm{pH} 2.8$ ) were applied to remove the cell surfacebound peptide. After that, the cells were washed one more time with $1 \times$ phosphate-buffered saline $(\mathrm{pH} 7.4)$. Subsequently, cells were lysed with $0.3 \mathrm{M} \mathrm{NaOH}(0.5 \mathrm{~mL})$. Radioactivity was determined with a $\gamma$-counter and calculated as percentage of the applied dose per $10^{6}$ cells. Each experiment was performed in triplicate and repeated 3 times.

\section{Stability Experiments}

Serum stability measurements were done with $2.3 \times 10^{6} \mathrm{cpm}$ of ${ }^{125} \mathrm{I}$-labeled HBP-1. The peptide was incubated in human serum at $37^{\circ} \mathrm{C}$. Aliquots were taken at several time points, and the degradation was stopped by precipitation of the serum proteins with 1 volume of acetonitrile. After incubation on ice and several centrifugation steps at $1.3 \times 10^{6} \mathrm{rpm}$, the clear supernatant was analyzed by reverse-phase HPLC on a Chromolith Performance RP-18e $100 \times 4.6 \mathrm{~mm}$ column using water and acetonitrile containing $0.1 \%$ trifluoroacetic acid.

Fragment analyses were done with $10^{-3} \mathrm{M}$ unlabeled HBP-1 resolved in $1 \mathrm{~mL}$ of human serum. After incubation for $1 \mathrm{~h}$ at $37^{\circ} \mathrm{C}, 8$ peaks were collected by HPLC separation. Four different masses could be determined by electrospray ionization. Each experiment was performed 2 times.

\section{In Vivo Biodistribution of ${ }^{131}$ I-HBP-1}

Female 6-wk-old BALB/c nu/nu mice weighing 15-19 g were obtained from Charles River WIGA and housed in VentiRacks (BioZone Global). For inoculation of the tumors in nude mice, a cell suspension of $4 \times 10^{6}$ cells in OPTI-MEM (Gibco, Invitrogen Life Technologies) was injected subcutaneously into the anterior region of the mouse trunk for the HNO97 tumors and into the upper part of the hind leg for HNO210 tumors. Tumors were grown to a size of about $0.5 \mathrm{~cm}^{3}$. For the in vivo experiment, a larger amount of radioactive labeled HBP-1 is required. Therefore HBP-1 was labeled with ${ }^{131}$ I because of the shorter life-time of $8 \mathrm{~d}$, in comparison with $60 \mathrm{~d}$ for ${ }^{125} \mathrm{I}$. ${ }^{131} \mathrm{I}$-HBP-1 was injected into the tail vein of the animals. At 5, 15, 45, and 135 min after injection, the mice were sacrificed, blood and organs were removed and weighed, and the radioactivity was determined using an automated $\mathrm{NaI}$ ( $\mathrm{Tl}$ ) well counter (Cobra II; Canberra Packard). The percentage injected dose per gram $(\% \mathrm{ID} / \mathrm{g})$ of tissue was calculated. All animals were cared for according to the national animal guidelines. Each experiment was performed in triplicate and repeated 3 times.

\section{Immunohistochemistry of HNSCC Tissue Slices}

Peptide staining was performed on cryostat sections $(5-7 \mu \mathrm{m})$ of frozen original HNSCC tumor tissues from the corresponding tumor samples HNO97, HNO210, HNO223, HNO237, and HNO222. The slides were mounted on a 3-aminopropyl-triethoxysilan-coated slide. Tumor sections were fixed with acetone at $-20^{\circ} \mathrm{C}$ for 10 min. Afterward, tumor tissues were incubated with FITC-HBP-1 $\left(10^{-5} \mathrm{M}\right)$ for $60 \mathrm{~min}$ at room temperature. After 3 washing steps, the sample was incubated with a biotin-conjugated monoclonal mouse anti-FITC antibody (Sigma) for $30 \mathrm{~min}$ followed by a secondary antimouse antibody applying the PK6102 mouse IgG ABC Kit (Vectastain Laboratories) as described elsewhere (11).
Bright-field pictures were taken with a BX 50 microscope (Olympus) and AnalySIS image analysis software (Soft Imaging System). Each experiment was performed in duplicate and repeated 2 times.

\section{RESULTS}

\section{Identification of HNSCC-Binding Peptide HBP-1}

Five selection rounds were performed on the HNO223 HNSSC cell line with a linear 12-amino-acid peptide library to allow for enrichment of tumor cell binding or internalizing phages. Before each selection round, a negative selection with the keratinocyte cell line HPV-16GM was performed to subtract phages that bound to nontumor cells. After the final selection round, single-stranded DNAs of 21 clones were sequenced and analyzed. One sequence was found to be enriched in $62 \%$ of all sequenced clones and termed HBP. The other isolated sequences did not bear any similarity to HBP and did not show second-motif enrichment. HBP is a 12-amino-acid long linear peptide comprising the sequence $\mathrm{H}_{2} \mathrm{~N}-\mathrm{SPRGDLAVLGHK}-\mathrm{CONH}_{2}$. For all further experiments, an additional tyrosine was added to the $\mathrm{C}$ terminus of HBP, which is named HBP-1 henceforward. HBP-1 comprises 2 known sequence motifs; the RGD and the LXXL motifs, which are in the direct neighborhood of each other.

\section{Characterization of Uptake, Kinetics, $\mathrm{IC}_{50}$, and} Internalization of HBP-1

HBP-1 was synthesized by Fmoc solid-phase chemistry and labeled with ${ }^{125} \mathrm{I}$. HNSSC cells were incubated for 30 min with ${ }^{125}$ I-HBP-1. After unbound peptide had been removed, the cells were lysed and the binding was calculated as percentage of the applied dose per $10^{6}$ cells. ${ }^{125} \mathrm{I}-\mathrm{HBP}-1$ showed binding to all 5 HNSCC cell lines, with a maximum of $11 \%$ for $\mathrm{HNO} 97,10 \%$ for $\mathrm{HNO} 222,7.5 \%$ for $\mathrm{HNO} 237$, and $6 \%$ for $\mathrm{HNO} 210$ (Fig. 1A). For HNO223 cells, which were used for the selection of HBP-1, 5\% binding could be determined. ${ }^{125} \mathrm{I}-\mathrm{HBP}-1$ did not show any significant binding to isolated human endothelial cells. Interestingly, ${ }^{125} \mathrm{I}-\mathrm{HBP}-1$ revealed $8 \%$ uptake to the human breast cancer cell line MCF-7 but not to the benign breast cell line MCF-10A. In addition, ${ }^{125}$ I-HBP-1 showed an uptake of between $1 \%$ and $3 \%$ to 4 colon carcinoma cell lines, 2 thyroid cancer cell lines, 1 lung cancer cell line, 1 prostate cancer cell line, and 1 cervical carcinoma cell line (cell lines: HT 29, SW948, CaCo2, HCT116, C643, FRO82-2, A549, PC-3, and HeLa). To confirm the specificity of the binding, $10^{-4} \mathrm{M}$ unlabeled HBP-1 as competitor was coincubated with the radioactive peptide. For all tested cancer cell lines, a strong competition was obtained, with values below $1 \%$ of binding. Investigation of the binding kinetics to HNO97 cells revealed an increase in ${ }^{125} \mathrm{I}-\mathrm{HBP}-1$ binding until a maximum was reached at $30 \mathrm{~min}$, followed by a decrease until a steady-state binding of about $4 \%$ was reached at $240 \mathrm{~min}$ (Fig. 1B). Incubation of HNO97 cells with ${ }^{125} \mathrm{I}-\mathrm{HBP}-1$ in the presence of increasing concentrations of unlabeled HBP-1 as competitor $\left(10^{-10} \mathrm{M}-10^{-4} \mathrm{M}\right)$ showed strong inhibition at higher concentrations, and an 

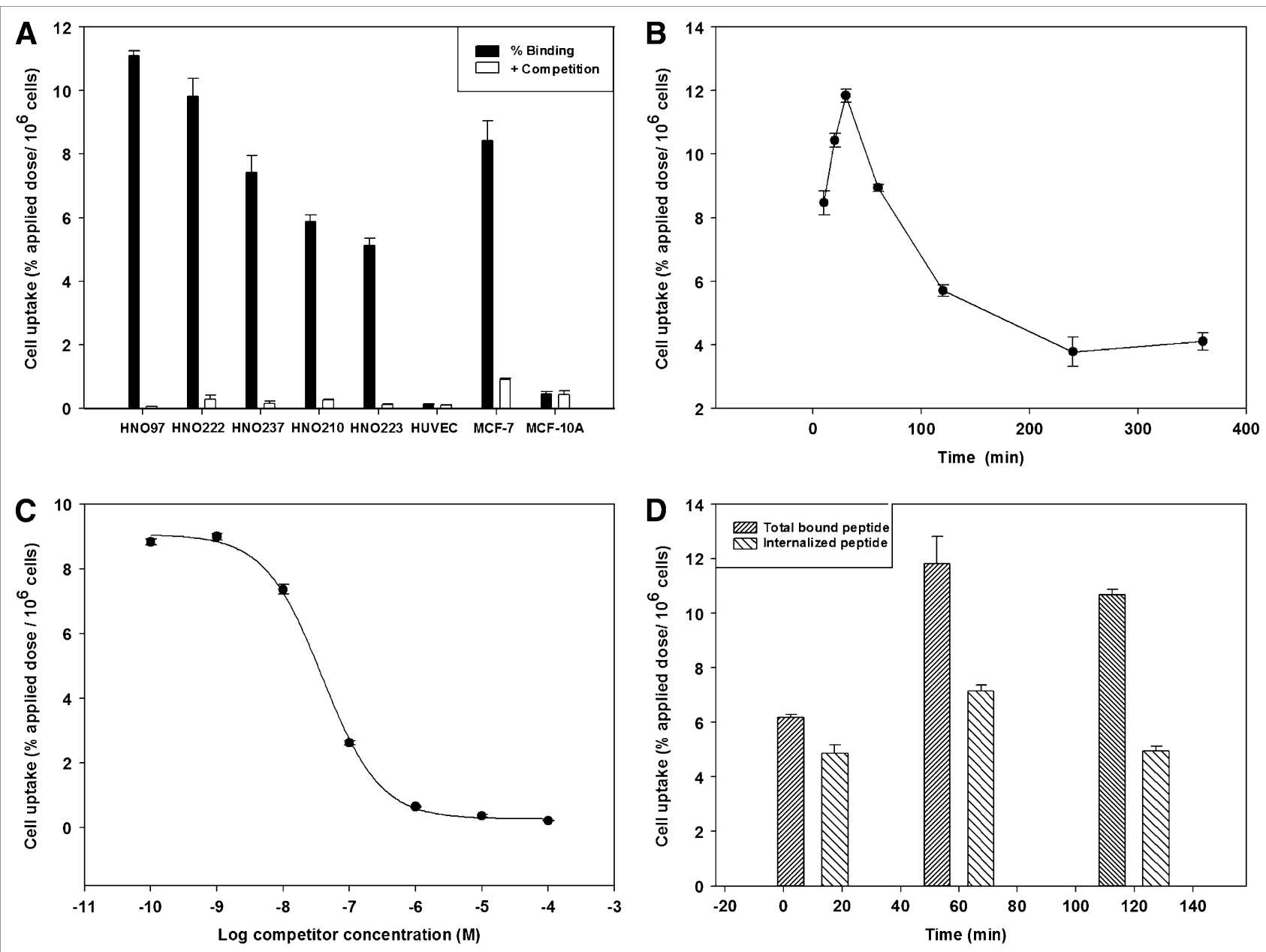

FIGURE 1. In vitro characterization. (A) Binding of $125 \mathrm{I}-\mathrm{HBP}-1$ to HNSCC cell lines HNO97, HNO222, HNO237, HNO210, HNO223; benign human umbilical vein endothelial cells; MCF-7 cancer cell line; and benign MCF-10A cells (\% binding indicates that ${ }^{125}$-labeled HBP-1 was incubated for 30 min with cells; + competition indicates that unlabeled HBP-1 [10 $\left.{ }^{-4} \mathrm{M}\right]$ was added as competitor at same time as $\left.{ }^{125} \mathrm{I}-\mathrm{HBP}-1\right)$. (B) Kinetics with ${ }^{125} \mathrm{I}-\mathrm{HBP}-1$ binding to HNO97 cells after 10, 20, 30, 60, 120, 240, and $360 \mathrm{~min}$. (C) Competition curve of ${ }^{125} \mathrm{I}-\mathrm{HBP}-1$ with HNO97 cells using unlabeled HBP-1 as competitor from $10^{-10} \mathrm{M}$ up to $10^{-4} \mathrm{M}$. An $\mathrm{IC}_{50}$ value of $38.9 \mathrm{nM}$ could be determined. (D) Internalization of ${ }^{125} \mathrm{I}-\mathrm{HBP}-1$ with $\mathrm{HNO} 97$ cells at $37^{\circ} \mathrm{C}$ determined after 10, 60, and 120 min of incubation. Each value represents mean and SD of 3 samples.

inhibitory concentration of $50 \%$ ( $\mathrm{IC}_{50}$ ) of $38.9 \mathrm{nM}$ (Fig. 1C) could be ascertained. ${ }^{125} \mathrm{I}-\mathrm{HBP}-1$ showed fast internalization at $37^{\circ} \mathrm{C}$ into $\mathrm{HNO} 97$ cells, with values of $78.6 \%, 60.5 \%$, and $46.3 \%$ of total bound peptide after 10,60 , and $120 \mathrm{~min}$, respectively, past the start of incubation (Fig. 1D).

\section{In Vivo Distribution of ${ }^{131}$ I-HBP-1 Using Tumor-Bearing Nude Mice}

For investigation of HBP-1 organ distribution, BALB/c $n u / n u$ mice with HNO97 and HNO210 tumors were injected intravenously (tail vein) with ${ }^{131}$ I labeled HBP-1 (Figs. 2A and 2B), and the accumulated radioactivity was calculated as $\% \mathrm{ID} / \mathrm{g}$ (Table 1). In the tumor, an initial activity of almost $7 \% \mathrm{ID} / \mathrm{g}$ for $\mathrm{HNO} 97$ and $6 \% \mathrm{ID} / \mathrm{g}$ for $\mathrm{HNO} 210$ could be observed, followed by washout of the tumor tissue to a level of, still, $5 \% \mathrm{ID} / \mathrm{g}$ at $45 \mathrm{~min}$ after injection. The kidneys at first had the highest uptake, at $15 \% \mathrm{ID} / \mathrm{g}$ and $11 \% \mathrm{ID} / \mathrm{g}$, followed by a rapid clearance to $30 \%$ of the initial value. In the blood, the radioactivity decreased to $40 \%$ and $33 \%$ of the initial value. The retention time of ${ }^{131} \mathrm{I}-\mathrm{HBP}-1$ in the tumor was significantly higher than in the blood and other organs. Tumor-to-tissue ratios were mostly above 1 , indicating tumor accumulation, except for kidney and lung (Table 2). For a biodistribution of ${ }^{131}$ I-HBP-1 in HNO210 tumor-bearing mice (Fig. 2B), the radioactivity in the tumor tissue was 5.5 $\% \mathrm{ID} / \mathrm{g}$ for up to $45 \mathrm{~min}$ after injection.

\section{Binding of FITC-Labeled Peptide on HNSCC \\ Tissue Sections}

Bright-field analysis with FITC-HBP-1 was determined for 5 different HNSCC tumor samples, which corresponded to the 5 HNSCC cell lines used for the in vitro studies. For the 

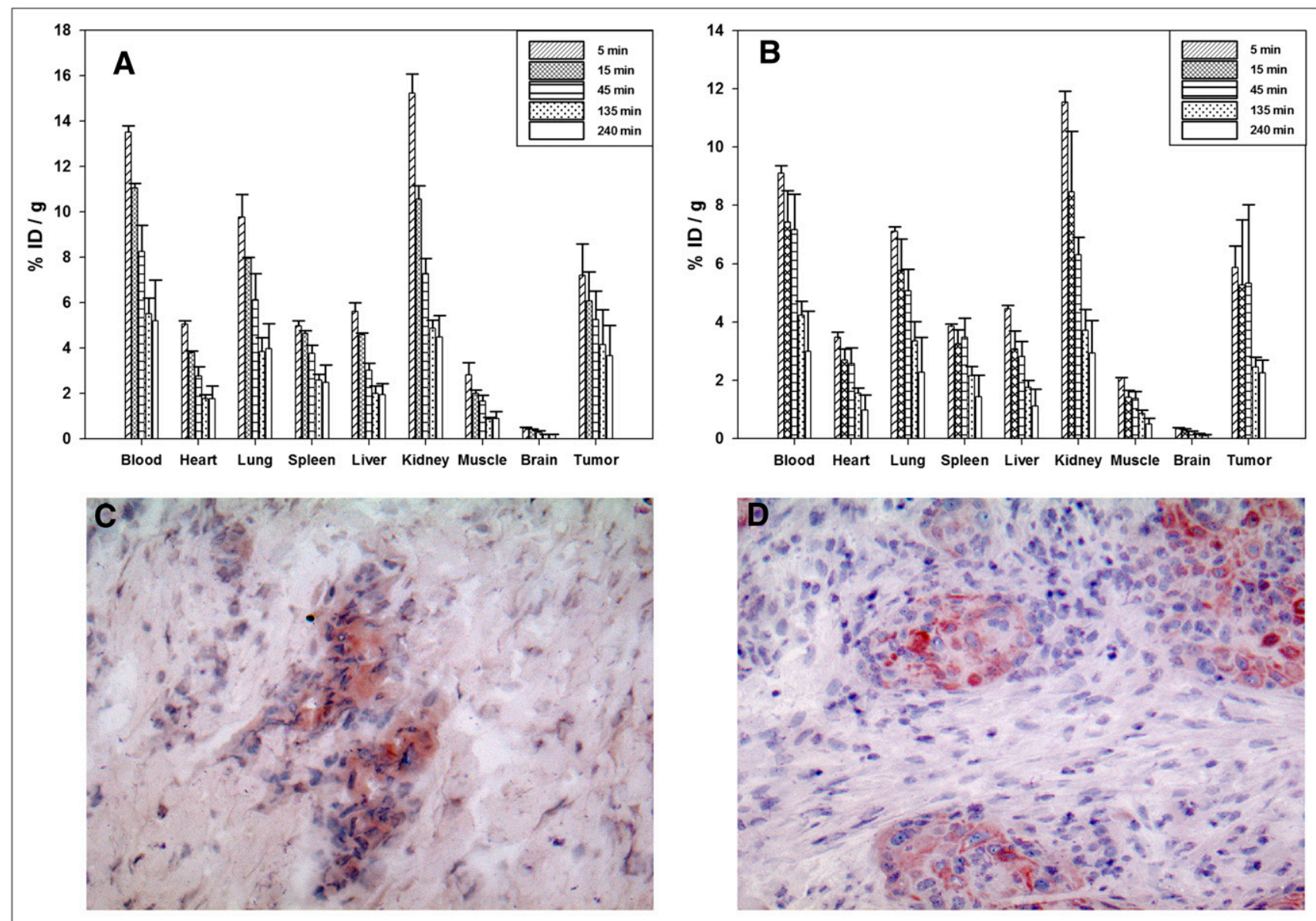

FIGURE 2. Biodistribution and binding to tumor tissue sections. (A) Organ distribution of ${ }^{131} \mathrm{I}-\mathrm{HBP}-1$ in HNO97 tumor-bearing nude mice. Radioactivity was measured in tumor and organs at 5, 15, 45, 135, and 240 min after injection and calculated as $\% \mathrm{ID} / \mathrm{g}$ (mean and SD are shown; $n=3$ per time point). (B) Organ distribution of ${ }^{131} \mathrm{I}-\mathrm{HBP}-1$ in HNO210 tumor-bearing nude mice. Radioactivity was measured in tumor and control organs after 5, 15, 45, 135, and 240 min after injection (mean and SD are shown; $n=3$ per time point). (C) Binding of HBP-1 on HNO97 tumor sections. FITC-HBP-1 stained areas of tumor appear red. Cell nuclei are stained with hematoxylin and appear blue. (D) Binding of HBP-1 on HNO210 tumor sections. FITC-HBP-1stained areas of tumor appear red. Cell nuclei are stained with hematoxylin and appear blue.

HNO97, HNO210, HNO223, and HNO222 samples, a moderate to strong staining was observed in most tumor cells (Figs. 2C and 2D), whereas the tumor-surrounding stroma appeared to be negative for FITC-HBP-1. For the HNO237 sample, no staining could be detected.

\section{Peptide Stability in Human Serum}

The stability of ${ }^{125}$ I-HBP-1 was analyzed in heparinized human serum at $37^{\circ} \mathrm{C}$. Analysis of samples taken at several time points revealed a half-life of $55 \mathrm{~min}$ (Fig. 3A). Further investigation of the observed fragments was performed. Unlabeled HBP-1 was incubated for $1 \mathrm{~h}$ in human serum at $37^{\circ} \mathrm{C}$, and 8 fragments could be collected after reversephase HPLC chromatographic separation (Fig. 3B). The corresponding masses were determined by electrospray ionization mass spectrometry. Applying the known mass of HBP-1 and of possible shorter forms of HBP-1, we could determine the sequence of 3 different fragments: HBP-F1, -F2, and -F3. All 3 fragments are due to $\mathrm{N}$-terminal degradation of HBP-1 (Table 3).

\section{Binding Sequence and Target Analysis of HBP-1}

To reveal the crucial amino acids primarily contributing to the HBP-1 percentage uptake, mutations of the intrinsic RGD motif and the adjacent LXXL motif were evaluated. The RGD motif was mutated to AGA, and LXXL to AXXA, resulting in 2 peptides named ${ }^{125} \mathrm{I}-\mathrm{HBP}-\mathrm{AGA}$ and ${ }^{125} \mathrm{I}-\mathrm{HBP}-$ AXXA (Table 3). Binding studies with HNO97 cells revealed only $2 \%$ of the primary uptake of ${ }^{125}$ I-HBP-1 for both mutations (Fig. 3C). Further investigation was addressed to the nature of the target. Two peptides that are known to target $\alpha_{v} \beta_{6}$ receptors were used to compete with ${ }^{125}$ I-HBP-1 binding. Both AA20FMDV2 and TP H2009.1 were able to suppress ${ }^{125}$ I-HBP-1 binding up to $98 \%(12,13)$. In addition, the commercially available circular peptide cRGD, which is known to bind to $\alpha_{\mathrm{v}} \beta_{3}$ receptors, was used as competitor. A 


\begin{tabular}{|c|c|c|c|c|c|c|c|c|c|}
\hline Tumor type & Blood & Heart & Lung & Spleen & Liver & Kidney & Muscle & Brain & Tumor \\
\hline \multicolumn{10}{|l|}{ HNO97 } \\
\hline $5 \min$ & 13.52 & 5.04 & 9.78 & 4.98 & 5.62 & 15.22 & 2.81 & 0.45 & 7.19 \\
\hline $15 \mathrm{~min}$ & 11.04 & 3.79 & 7.95 & 4.64 & 4.58 & 10.57 & 1.99 & 0.41 & 6.08 \\
\hline $45 \min$ & 8.26 & 2.76 & 6.11 & 3.77 & 3.01 & 7.27 & 1.65 & 0.28 & 5.26 \\
\hline $135 \mathrm{~min}$ & 5.51 & 1.77 & 3.85 & 2.58 & 2.00 & 4.87 & 0.86 & 0.17 & 4.15 \\
\hline $240 \mathrm{~min}$ & 5.19 & 1.76 & 3.96 & 2.49 & 1.94 & 4.48 & 0.89 & 0.16 & 3.66 \\
\hline \multicolumn{10}{|l|}{ HNO210 } \\
\hline $5 \mathrm{~min}$ & 9.11 & 3.47 & 7.12 & 3.86 & 4.46 & 11.53 & 2.08 & 0.34 & 5.87 \\
\hline $15 \mathrm{~min}$ & 7.43 & 2.69 & 5.77 & 3.26 & 3.08 & 8.46 & 1.42 & 0.29 & 5.27 \\
\hline $45 \mathrm{~min}$ & 7.18 & 2.58 & 5.08 & 3.48 & 2.82 & 6.32 & 1.39 & 0.24 & 5.32 \\
\hline $135 \mathrm{~min}$ & 4.24 & 1.56 & 3.35 & 2.16 & 1.76 & 3.71 & 0.87 & 0.16 & 2.47 \\
\hline $240 \mathrm{~min}$ & 3.00 & 0.99 & 2.28 & 1.44 & 1.12 & 2.93 & 0.50 & 0.10 & 2.26 \\
\hline
\end{tabular}

$63 \%$ decrease of ${ }^{125}$ I-HBP-1 binding could be observed with the cyclic peptide competitor. In contrast, unlabeled HBP-1 as competitor resulted in a $99.7 \%$ decrease in binding (Table 4).

\section{DISCUSSION}

Targeted therapies represent an attractive approach to circumventing the nonspecific cytotoxicity of conventional anticancer treatments. Peptides do provide the advantage of small molecules, an advantage that enables them to serve as promising carrier molecules for drug targeting or as tracer molecules for tumor imaging. Until now, several peptides have exhibited promising features as lead molecules for targeted therapies (14). Somatostatin, the most prominent example for tumor-targeting peptides with its derivates ${ }^{111}$ In-pentetreotide (OctreoScan; Covidien) and $\left[\right.$ DOTA $^{0}-\mathrm{Tyr}^{3}$ ]octreotide, is used for diagnosis and for radiopeptide therapy $(15,16)$. The available data for somatostatin analogs encourage further studies addressing the identification of new tumor-binding peptides. Such studies may be done using high-throughput systems such as phage display with peptide libraries.

By applying a 12 mer peptide library of great diversity to human HNSCC cell lines, we were able to select the binding peptide HBP-1. This peptide was found to be enriched in $62 \%$ of all sequenced clones. The sequence of HBP-1 comprises an RGD motif that is known to bind with high affinity to integrin receptors. The most prominent role of this receptor family is the regulation of proliferation, differentiation, and migration and the maintenance of tissue integrity (17). During tumorigenesis, the expression pattern and the cellular localization of various integrins are subjected to significant changes $(18,19)$. Such changes have also been found in HNSCC, for which many integrin receptors are downregulated, except for $\alpha_{v} \beta_{3}$, which is overexpressed; other integrins show de novo expression, as has been demonstrated for $\alpha_{v} \beta_{6}$ and $\alpha_{6} \beta_{4}$ dimers $(20,21)$. RGD motif peptides and various modified versions of RGD containing molecules such as peptidomimetics, pseudopeptides, and disintegrins (venom-derived) have been studied for their usefulness for cancer treatment or disease-related angiogenesis treatment (peptidomimetics (22), pseudopeptides (23), venom (24)). Cilengitide (cyclo(Arg-Gly-Asp-D-Phe-[NMe]Val)) (Merck $\mathrm{KGaA}$ ) is a peptide in phase I and II trials dealing with a variety of solid tumors and neovascular endothelial cells $(25,26)$. In an initial study, cilengitide led to a partial response in highly vascularized head and neck tumors (4).

A prerequisite for the potential application of HBP-1 in imaging and therapy is its percentage of uptake. HBP-1 exhibits high affinity $\left(\mathrm{IC}_{50}\right.$ of $\left.38.9 \mathrm{nM}\right)$ and in vitro binding to HNO97 cells ( $\leq 11 \%$ applied dose per $10^{6}$ cells). In addition,

\section{TABLE 2. ${ }^{131} \mathrm{I}-\mathrm{HBP}-1$ Tumor-to-Tissue Ratio of HNO97 and HNO210 Tumors}

\begin{tabular}{|c|c|c|c|c|c|c|c|c|c|c|}
\hline \multirow[b]{3}{*}{ Tissue } & \multicolumn{10}{|c|}{ Tumor-to-tissue ratio } \\
\hline & \multicolumn{5}{|c|}{ HNO97 tumors } & \multicolumn{5}{|c|}{ HNO210 tumors } \\
\hline & $5 \mathrm{~min}$ & $15 \mathrm{~min}$ & $45 \mathrm{~min}$ & $135 \mathrm{~min}$ & $240 \mathrm{~min}$ & $5 \mathrm{~min}$ & $15 \min$ & $45 \mathrm{~min}$ & $135 \mathrm{~min}$ & $240 \mathrm{~min}$ \\
\hline Blood & 0.5 & 0.6 & 0.6 & 0.8 & 0.7 & 0.6 & 0.7 & 0.7 & 0.6 & 0.8 \\
\hline Heart & 1.4 & 1.6 & 1.9 & 2.4 & 2.1 & 1.7 & 2.0 & 2.1 & 1.6 & 2.3 \\
\hline Lung & 0.7 & 0.8 & 0.9 & 1.1 & 0.9 & 0.8 & 0.9 & 1.0 & 0.7 & 1.0 \\
\hline Spleen & 1.4 & 1.3 & 1.4 & 1.6 & 1.5 & 1.5 & 1.6 & 1.5 & 1.1 & 1.6 \\
\hline Liver & 1.3 & 1.3 & 1.7 & 2.1 & 1.9 & 1.3 & 1.7 & 1.9 & 1.4 & 2.0 \\
\hline Kidney & 0.5 & 0.6 & 0.7 & 0.9 & 0.8 & 0.5 & 0.6 & 0.8 & 0.7 & 0.8 \\
\hline Muscle & 2.6 & 3.1 & 3.2 & 4.8 & 4.1 & 2.8 & 3.7 & 3.8 & 2.9 & 4.6 \\
\hline Brain & 15.9 & 14.8 & 18.5 & 24.7 & 22.2 & 17.2 & 18.3 & 21.9 & 15.9 & 22.3 \\
\hline
\end{tabular}




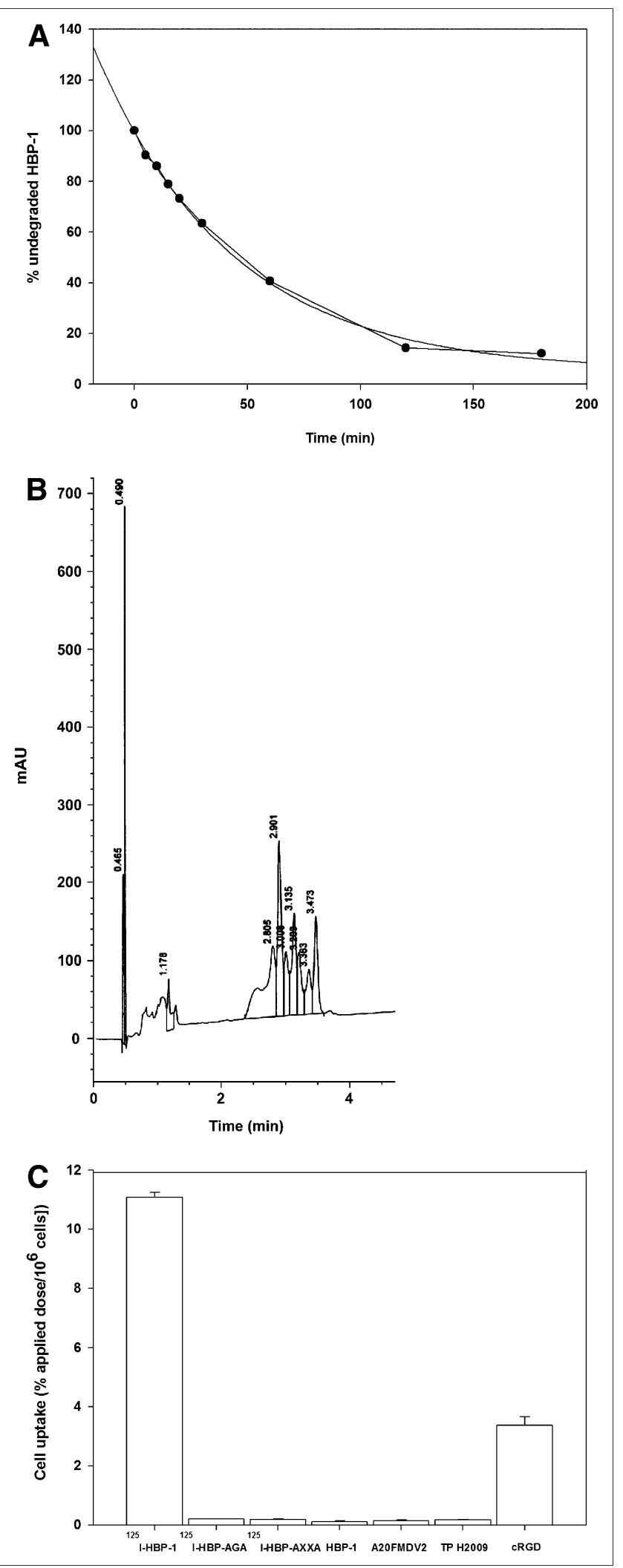

FIGURE 3. Serum stability and binding sequence/target relation: (A) Serum stability of HBP-1 in human serum at $37^{\circ} \mathrm{C}$. Incubation was stopped after $5,10,15,20,30,60$, 180 , and 240 min and analyzed by HPLC. (B) HPLC graph of the 8 collected HBP-1 fragment peaks (peak 2.805 to peak

\section{TABLE 3. Serum Digestion Fragments}

\begin{tabular}{llc} 
Peptide & \multicolumn{1}{c}{$\begin{array}{c}\text { Serum } \\
\text { degradation fragments }\end{array}$} & $\begin{array}{c}\text { Calculated } \\
\text { mass }(\mathrm{g} / \mathrm{mol})\end{array}$ \\
HBP-1 & S-P-R-G-D-L-A-V-L-G-H-K-Y & 1,411 \\
HBP-F1 & R-G-D-L-A-V-L-G-H-K-Y & 1,227 \\
HBP-F2 & G-D-L-A-V-L-G-H-K-Y & 1,071 \\
HBP-F3 & D-L-A-V-L-G-H-K-Y & 1,014 \\
\hline
\end{tabular}

binding was observed in all 4 other HNSCC cell lines, including 5\% binding to $\mathrm{HNO} 223$, which has been used for the panning procedure. The breast cancer cell line MCF-7, with an average of $8 \%$ binding, and several other cancer cell lines (lung, cervix, pancreas, and colon) with up to $3 \%$ binding provide evidence of a broader applicability in solid tumors. Interestingly, HBP-1 showed no significant binding to endothelial cells, a finding that is in contrast to findings with linear and cyclic RGD peptides used as incorporation enhancers of photosensitizers for $\alpha_{v} \beta_{3}$ integrin-positive human umbilical vein endothelial cells (27). In view of this finding, HBP-1 might not target the classic integrin receptor $\alpha_{\mathrm{v}} \beta_{3}$.

Staining of human tumor samples, which corresponded to the HNSCC cell lines, with fluorescence-labeled HBP-1 revealed positive results in 4 of 5 tested tumors but not in HNO237. Negative staining results could be due to inhomogeneous integrin distribution in the tumor, lower expression than in the other tumors, or higher integrin expression in the derived cell line than in the original tumor sample. Therefore, the results for tissue staining and the HNSSC cell lines underline the potential for an application in cancer patients. In biodistribution experiments, HBP-1 accumulated in HNO97 and HNO210 tumors with relatively stable uptake until $45 \mathrm{~min}$ after injection. The overall retention time in both tumors types was greater than that in the measured organs and the blood. The relatively high values in the blood and kidneys may be due to peptide degradation resulting in labeled fragments circulating in the bloodstream. Another reason could be deiodination and excretion of free iodide via the kidneys. For a possible application in tumor imaging, the blood background needs to be reduced by peptide modification. A comparable or higher retention could be determined in the lungs and for the spleen, with tumor-to-tissue ratios of 1 or less, and can be explained by the expression of $\alpha_{v} \beta_{6}$ integrins on lung epithelial cells, which are involved in downregulating epithelial inflammation (28). In comparison with a linear RGD peptide (13mer) studied by Sutcliffe-Goulden et al., ${ }^{131}$ I-HBP-1 displays a significantly higher tumor-totissue ratio (29). The cyclic ${ }^{18} \mathrm{~F}$-galacto-RGD showed higher tumor-to-tissue ratios in a melanoma model, except for liver,

3.473) after $1 \mathrm{~h}$ of incubation in human serum at $37^{\circ} \mathrm{C}$. (C) In vitro binding studies of ${ }^{125} \mathrm{I}-\mathrm{HBP}-1$ in comparison with motif mutants ${ }^{125} \mathrm{I}-\mathrm{HBP}-\mathrm{AGA}$ and ${ }^{125} \mathrm{I}-\mathrm{HBP}-\mathrm{AXXA}$ to HNO97 cells. In addition, competition of $125 \mathrm{l}-\mathrm{HBP}-1$ binding to HNO97 cells with unlabeled cRGD, TP H2009.1, and A20FMDV2 is shown. 
TABLE 4. Modifications and Competitors

$\begin{array}{llll}\text { Peptide } & \text { Modifications of HBP-1 and competitors } & \% \text { binding* }^{*} & \text { Competition }^{*} \\ \text { HBP-1 } & \text { S-P-R-G-D-L-A-V-L-G-H-K-Y } & 11.1 \% & 99.9 \% \\ \text { HBP-AGA } & \text { S-P-A-G-A-L-A-V-L-G-H-K-Y } & 0.2 \% & \\ \text { HBP-AXXA } & \text { S-P-R-G-D-A-A-V-A-G-H-K-Y } & 0.2 \% & 99.9 \% \\ \text { TP H2009.1 } & \text { R-G-D-L-A-T-L-R-Q-L-A-Q-E-D-G-V-V-G-V-R-Y } & 99.9 \% \\ \text { A2OFMDV2 } & \text { N-A-V-P-N-L-R-G-D-L-Q-V-L-A-Q-K-V-A-R-T-Y } & 99.8 \% \\ \text { C-RGD } & \text { cyclo-(R-G-D-d-F-V) } & & \\ & & & \\ { }^{*} \text { Applied dose per } 10^{6} \text { cells. }\end{array}$

with 0.8 after $60 \mathrm{~min}(1.2=120 \mathrm{~min})$, compared with 1.7 after $45 \mathrm{~min}(2.1=135 \mathrm{~min})$ for ${ }^{131} \mathrm{I}$-HBP-1 (30).

HBP-1 is different from common cyclic RGD peptides. This difference was shown by a competition experiment in which ${ }^{125} \mathrm{I}$-HBP1 binding in the presence of unlabeled HBP-1 decreased to $0.3 \%$ whereas a commercially available cRGD peptide cyclo-(RGDdFV) could reduce the ${ }^{125}$ I-HBP1 uptake only to $63 \%$. As mentioned before, RGD peptides are known to target predominantly the integrin receptor $\alpha_{v} \beta_{3}$. Because of this result, further validation of the binding sequence by sequence mutation experiments was performed. Indeed, the alteration of the RGD motif to AGA led to virtually no binding. But the alteration of the adjacent LAVL sequence to AAVA led to a loss of binding, too. The amino acids in the vicinity of the RGD motif may play a major role in the determination of binding specificity and affinity (31). Considering the fact that both sequences are required to provide the full percentage uptake, HBP-1 might target not the classic RGD peptide receptor $\alpha_{v} \beta_{3}$ but the receptor subtypes $\alpha_{v} \beta_{6}$ and $\alpha_{6} \beta_{4}$, subtypes that are known to be de novo expressed in HNSCC $(18,21,32)$. Interestingly, 2 recent publications of RGD peptides, TP H2009.1 and A20FMDV2, reported this so-called LXXL motif in combination with an adjacent RGD motif. Both results clearly indicated specificity for the $\alpha_{v} \beta_{6}$ integrin receptor $(12,13)$. Competition experiments with these two 20-amino-acid long peptides showed an entire suppression of ${ }^{125} \mathrm{I}-\mathrm{HBP}-1$ binding to HNO97 cells. Additionally, all HNSCC cell lines were tested by fluorescence-activated cell sorter analysis for the presence of $\alpha_{v} \beta_{6}$ integrin receptor and appeared to be positive. This is evidence that HBP- 1 is targeting the $\alpha_{\mathrm{v}} \beta_{6}$ integrin receptor. The fact that $\alpha_{\mathrm{v}} \beta_{6}$ is de novo expressed in cancer makes HBP-1 an even more suitable molecule for effective tumor imaging and therapy.

Besides the percentage uptake, another important prerequisite for in vivo application of targeting peptides is their stability. Incubation of HBP-1 in human serum revealed a half-life of $55 \mathrm{~min}$, which is better than the half-life for both of the compared linear RGDLXXL motif containing peptides, TP H2009.1 and A20FMDV2, at 14.5 and 42 min, respectively. Nevertheless, this improved half-life is still not as good as the features provided by the cyclic ${ }^{18} \mathrm{~F}$-galactoRGD peptide (cilengitide), which exhibits $95 \%$ intact pep- tide 120 min after injection in humans (33). Investigation of the observed fragments $60 \mathrm{~min}$ after the start of incubation showed a stepwise $\mathrm{N}$ terminus degradation.

In addition, a specific and fast internalization is desirable for rapid tumor binding and uptake, resulting in a higher effect on the tumor and longer drug retention in the cells (34). With $78.6 \%$ internalization after $10 \mathrm{~min}$ of incubation with HNO97 cells, HBP-1 shows high potential for fast tumor uptake. The decrease of intracellular radioactivity to $60.5 \%$ and $46.3 \%$ after 60 and $120 \mathrm{~min}$, respectively, is likely to be due to cytosolic peptide degradation.

The lead structure of HBP-1 might be modified to improve its binding affinity, stability, and blood clearance. Strategies of peptide stabilization are cyclization, incorporation of D-amino acids, capping modifications, and pegylation or protection by a chelator molecule. Pegylation and coupling to chitin derivates influence the peptide pharmacokinetics and retention time $(35,36)$. These modifications may lead to changes in the secondary structure of the peptide and influence its affinity. Multimerization is a promising approach to increasing the percentage uptake of peptides, by maintaining most likely their secondary structure (34). For applications in patients, it is important to consider the toxicity of a new compound. Because other RGD peptides were found to be cytotoxic by themselves (37), toxicity has to be investigated for HBP-1, too.

\section{CONCLUSION}

At present, HBP-1 combines promising properties as a tumor-binding molecule and as a lead structure for further modification. It has the extraordinary feature of being linear but relatively stable, compared with other linear peptides. In addition, the $\alpha_{\mathrm{v}} \beta_{6}$ receptor provides great potential for tumor targeting. After further improvements, this new targeting molecule could be of considerable importance as a diagnostic or therapeutic agent for head and neck tumors and other tumors with $\alpha_{v} \beta_{6}$ receptor overexpression.

\section{REFERENCES}

1. Reuter CW, Morgan MA, Eckardt A. Targeting EGF-receptor-signalling in squamous cell carcinomas of the head and neck. Br J Cancer. 2007;96:408-416. 
2. Reubi JC. Peptide receptors as molecular targets for cancer diagnosis and therapy. Endocr Rev. 2003;24:389-427.

3. Matar P, Rojo F, Cassia R, et al. Combined epidermal growth factor receptor targeting with the tyrosine kinase inhibitor gefitinib (ZD1839) and the monoclonal antibody cetuximab (IMC-C225): superiority over single-agent receptor targeting. Clin Cancer Res. 2004;10:6487-6501.

4. Raguse JD, Gath HJ, Bier J, Riess H, Oettle H. Cilengitide (EMD 121974) arrests the growth of a heavily pretreated highly vascularised head and neck tumour. Oral Oncol. 2004;40:228-230.

5. Szardenings M. Phage display of random peptide libraries: applications, limits, and potential. J Recept Signal Transduct Res. 2003;23:307-349.

6. Haberkorn U, Eisenhut M, Altmann A, Mier W. Endoradiotherapy with peptides: status and future development. Curr Med Chem. 2008;15:219-234.

7. Ninck S, Reisser C, Dyckhoff G, Helmke B, Bauer H, Herold-Mende C. Expression profiles of angiogenic growth factors in squamous cell carcinomas of the head and neck. Int J Cancer. 2003;106:34-44.

8. Jaffe EA, Nachman RL, Becker CG, Minick CR. Culture of human endothelial cells derived from umbilical veins: identification by morphologic and immunologic criteria. J Clin Invest. 1973;52:2745-2756.

9. Wellings DA, Atherton E. Standard Fmoc protocols. Methods Enzymol. 1997; 289:44-67.

10. Crim JW, Garczynski SF, Brown MR. Approaches to radioiodination of insect neuropeptides. Peptides. 2002;23:2045-2051.

11. Herold-Mende C, Seiter S, Born AI, et al. Expression of CD44 splice variants in squamous epithelia and squamous cell carcinomas of the head and neck. J Pathol. 1996;179:66-73.

12. DiCara D, Rapisarda C, Sutcliffe JL, et al. Structure-function analysis of ArgGly-Asp helix motifs in alpha v beta 6 integrin ligands. J Biol Chem. 2007; 282:9657-9665.

13. Elayadi AN, Samli KN, Prudkin L, et al. A peptide selected by biopanning identifies the integrin alphavbeta6 as a prognostic biomarker for nonsmall cell lung cancer. Cancer Res. 2007;67:5889-5895.

14. Weiner RE, Thakur ML. Radiolabeled peptides in oncology: role in diagnosis and treatment. BioDrugs. 2005;19:145-163.

15. Reubi JC. Somatostatin and other peptide receptors as tools for tumor diagnosis and treatment. Neuroendocrinology. 2004;80 (suppl 1):51-56.

16. Wangler C, Buchmann I, Eisenhut M, Haberkorn U, Mier W. Radiolabeled peptides and proteins in cancer therapy. Protein Pept Lett. 2007;14:273-279.

17. Arnaout MA, Goodman SL, Xiong JP. Structure and mechanics of integrin-based cell adhesion. Curr Opin Cell Biol. 2007;19:495-507.

18. Danen EH. Integrins: regulators of tissue function and cancer progression. Curr Pharm Des. 2005;11:881-891.

19. Mizejewski GJ. Role of integrins in cancer: survey of expression patterns. Proc Soc Exp Biol Med. 1999;222:124-138.

20. Georgolios AK, Batistatou A, Charalabopoulos K. Integrins in head and neck squamous cell carcinoma (HNSCC): a review of the current literature. Cell Commun Adhes. 2005;12:1-8.

21. Thomas GJ, Jones J, Speight PM. Integrins and oral cancer. Oral Oncol. 1997;33:381-388.
22. Harris TD, Kalogeropoulos S, Nguyen T, et al. Structure-activity relationships of ${ }^{111} \mathrm{In}$ - and ${ }^{99 \mathrm{~m}} \mathrm{Tc}$-labeled quinolin-4-one peptidomimetics as ligands for the vitronectin receptor: potential tumor imaging agents. Bioconjug Chem. 2006; 17:1294-1313.

23. Tsuchiya Y, Sawada S, Tsukada K, Saiki I. A new pseudo-peptide of Arg-GlyAsp (RGD) inhibits intrahepatic metastasis of orthotopically implanted murine hepatocellular carcinoma. Int J Oncol. 2002;20:319-324.

24. Swenson S, Costa F, Ernst W, Fujii G, Markland FS. Contortrostatin, a snake venom disintegrin with anti-angiogenic and anti-tumor activity. Pathophysiol Haemost Thromb. 2005;34:169-176.

25. Burke PA, DeNardo SJ, Miers LA, Lamborn KR, Matzku S, DeNardo GL. Cilengitide targeting of alpha(v)beta(3) integrin receptor synergizes with radioimmunotherapy to increase efficacy and apoptosis in breast cancer xenografts. Cancer Res. 2002;62:4263-4272.

26. Hehlgans S, Haase M, Cordes N. Signalling via integrins: implications for cell survival and anticancer strategies. Biochim Biophys Acta. 2007;1775:163-180.

27. Frochot C, Di Stasio B, Vanderesse R, et al. Interest of RGD-containing linear or cyclic peptide targeted tetraphenylchlorin as novel photosensitizers for selective photodynamic activity. Bioorg Chem. 2007;35:205-220.

28. Huang X, Wu J, Zhu W, Pytela R, Sheppard D. Expression of the human integrin beta6 subunit in alveolar type II cells and bronchiolar epithelial cells reverses lung inflammation in beta6 knockout mice. Am J Respir Cell Mol Biol. 1998;19:636-642.

29. Sutcliffe-Goulden JL, O'Doherty MJ, Marsden PK, Hart IR, Marshall JF, Bansal SS. Rapid solid phase synthesis and biodistribution of ${ }^{18} \mathrm{~F}$-labelled linear peptides. Eur J Nucl Med Mol Imaging. 2002;29:754-759.

30. Haubner R, Wester HJ, Weber WA, et al. Noninvasive imaging of alpha(v)beta3 integrin expression using ${ }^{18} \mathrm{~F}$-labeled RGD-containing glycopeptide and positron emission tomography. Cancer Res. 2001;61:1781-1785.

31. Vasudevan S, Celikel R, Ruggeri ZM, Varughese KI, Kunicki TJ. A single amino acid change in the binding pocket alters specificity of an anti-integrin antibody AP7.4 as revealed by its crystal structure. Blood Cells Mol Dis. 2004;32:176-181.

32. Herold-Mende C, Kartenbeck J, Tomakidi P, Bosch FX. Metastatic growth of squamous cell carcinomas is correlated with upregulation and redistribution of hemidesmosomal components. Cell Tissue Res. 2001;306:399-408.

33. Haubner R, Kuhnast B, Mang C, et al. $\left[{ }^{18} \mathrm{~F}\right]$ galacto-RGD: synthesis, radiolabeling, metabolic stability, and radiation dose estimates. Bioconjug Chem. 2004; 15:61-69.

34. Wester HJ, Kessler H. Molecular targeting with peptides or peptide-polymer conjugates: just a question of size? J Nucl Med. 2005;46:1940-1945.

35. Nishikawa N, Komazawa H, Orikasa A, et al. Synthesis and biological properties of partially modified retro and retro-inverso pseudo peptides of Arg-Gly-Asp (RGD). Bioorg Med Chem Lett. 1996;6:2725-2728.

36. Chen X, Hou Y, Tohme M, et al. Pegylated Arg-Gly-Asp peptide: ${ }^{64} \mathrm{Cu}$ labeling and PET imaging of brain tumor alphavbeta3-integrin expression. J Nucl Med. 2004;45:1776-1783.

37. Yang W, Meng $\mathrm{L}$, Wang $\mathrm{H}$, et al. Inhibition of proliferative and invasive capacities of breast cancer cells by arginine-glycine-aspartic acid peptide in vitro. Oncol Rep. 2006;15:113-117. 